\title{
How Leadership Styles in Academia Align to Achieve Success within the Tanzanian Catholic Universities System
}

\author{
Philbert L. Vumilia ${ }^{1}$, Ph. D. \\ ${ }^{1}$ Acting Vice Chancellor, Mwenge Catholic University, Tanzania \\ Correspondence: Philbert Vumilia, Vice Chancellor, Mwenge Catholic University, P.O. Box 1226 Moshi Tanzania. \\ Tel: 255-27-297-4110; Fax: 255-297-4108 E-mail: phasv19@hotmail.com; mwengeuniversity@gmail.com
}

Received: August 6, 2015

Accepted: September 5, 2015

Online Published: September 10, 2015

doi:10.5430/ijhe.v4n4p53

URL: http://dx.doi.org/10.5430/ijhe.v4n4p53

\begin{abstract}
Public and private universities in Kenya, Tanzania, Uganda, and elsewhere in Africa have been experiencing all-time high expansion since the late 1990s. This rush to expand both public and private universities has seriously impacted both the physical infrastructure as well as the effective leadership that new universities require. At the same time, the private sector has experienced dire shortages of teaching personnel and competent academic leaders. To shed light on these problems, this case study examined the dynamics of leadership roles exhibited in private universities and how leadership styles align to achieve success within Tanzania's Catholic Universities System. A case approach was used to study reports, journals, and interview data collected during 2007-2013 from universities selected purposely in order to understand better the success and effectiveness of academic leaders. The analysis revealed often perplexing assumptions that undergird the expectations of management operations, showed how leadership styles are perceived by incumbent academic leaders, and explained cross-cultural forces that govern, sustain, and sometimes frustrate leadership appointments.
\end{abstract}

Keywords: Academic leadership, Private higher education, Leadership styles, Catholic University System

\section{Introduction}

This case study examined the dynamics of leadership roles exhibited in private universities to determine how leadership styles align to achieve success within Tanzania's Catholic Universities System. A case approach was used to study reports, journals, interviews, and interview data collected during 2007-2013 from universities selected purposely in order to understand better the success and effectiveness of academic leaders. An "academic leader" refers to a person who has the ability and personality to influence the actions of others and to ensure that their actions correspond to the organizational requirements of the institution (Kenya Secondary School Heads Association, National Conference, 1999; Saleemi and Bogonko 1997).

Several theories in the literature were analyzed to inform this study particularly in light of the types of leadership styles that lead to success of the academic institution. Scholars maintain that successful leaders continually adapt to various situations and that different kinds of situations demand different leadership talents or traits to fit the new circumstances (Gorton, 1987; Méndez-Morse, 2000; Hord, 1992). These scholars further contend that to be successful, leaders need to demonstrate traits of intelligence, emotional maturity, stability, dependability, and consistency, among many other qualities. In recent studies, new information has surfaced indicating that overall competency in handling imminent tasks may explain the success of academic leaders.

For example, Marshall, Orrel, Cameron, Bosanquet and Thomas (2011) suggested two key responsibilities of academic leaders in learning and teaching institutions: (1) to develop institutional cultures in which learning and teaching is valued, rewarded, prioritized, and developed and (2) to develop and succinctly guide the curriculum operations as well as building and maintaining close interactions through which teamwork becomes the key leadership and management strategy. Likewise, Knight and Trowler (2001) argued that academic leaders function in four domains within which the quality of educational needs are cultivated and advanced. The domains included curriculum, staff, students, and organizational machinery. Together, these responsibilities suggest leadership roles of academic professionals working in complex environments, and perhaps supported in part by the "trait idea" that suggests the "great man theory" postulated in the 1800s by Thomas Carlyle (1841). 
Carlyle upheld the opinion that "successful leaders are born not made." Thus, to accomplish the leadership responsibilities successfully in all domains, academic leaders must assume many roles, including manager, budget and financial controller, organizer, counselor, and academic officer of the university. It seems therefore, in practice effective leaders ultimately assume the role of an engineer by creating human relations through interpersonal competence that motivates the organization (Sergiovanni, 1984). Perhaps even more importantly, the academic leader is expected to bring to the university campus expertise in effective teaching, educational program development, evaluation, and supervision (Uben, Hughes \& Noris, 2001). Therefore, this study also intended to shed light on how a leader can accomplish these functions in all four domains proposed by Knight and Trowler without extraordinary or superhuman powers.

Besides, with recent expansion of public and private universities in Kenya, Tanzania, Uganda, and elsewhere in Africa, universities in these countries experienced all-time high enrolments since the late 1990s (UNESCO, 2003). The dominant challenges and dilemmas facing the advocates of establishing these institutions can be summed up into premises: should new universities hire academic leaders from the pool of individuals with natural traits and innate characteristics of leadership or should they include those with long-term, innovative successful experiences but whose profiles do not fit the character or traditions of private institutions they are supposed to lead?

\section{Background and Context of the Research Problem}

The rapid proliferation of new African universities in recent years revealed gaps in the qualifications and calibre of academic leaders. Appointments of personnel—such as vice chancellors, chief academic officers (provosts), principals, and deans-were not easy to accomplish, and recruitment did not always yield qualified and capable candidates (TCU, 2012). In this case, the varied and evolving responsibilities apparent at new institutions and the leadership roles these institutions demanded ultimately determined the success or failure of new universities. The few individuals appointed to academic leadership positions quickly realized that they must shoulder many complex tasks that were often strikingly different than those tasks managed by their counterparts in Northern Europe or the US. For this reason, it seemed common to find African academic leaders playing multiple roles in order to carry out their leadership and management responsibilities successfully (UNESCO, 2003).

\subsection{Do Leadership Styles Align for Success in the Catholic Universities System?}

College and university leadership roles have well established common requisites, some of which point to distinctions that can be observed when the nature of the institution is examined. Often times, leadership positions are dictated by the nature of the university, whether public or private (TCU, 2012). Subsequently, the nature of the private Catholic university dictates the type of leaders being sought to manage its institutions. It is interesting, therefore, to question the qualities of academic leaders that the Catholic Universities System seeks.

Leaders of Catholic universities are expected to promote a university's growth and its community through a leadership of service, dedication, and witness (John Paul II, 1990). Obviously, the challenge is to implement Ex Corde Ecclesiae's principles and delineate its implications for appointments of academic leaders. Thus, the main task of Catholic university leaders, as explained in Pope John Paul II's Ex Corde Ecclesiae is to train students mentally, physically, morally, and psychologically by providing them with disciplinary content and professional knowledge required within prescribed levels (John Paul II, 1990). This task is complex, and rightly so, because it involves multifaceted processes that aim at the development of individuals as well as organizational contexts within which they operate (Marshall, 2006).

The vice chancellor or principal of the Catholic college plays many roles in order to conduct effectively his/her leadership responsibilities. Obviously, responsibilities come with challenges from within and outside the university that often contend with forces competing for the attainment of the university's mission. In such circumstances, several assumptions of academic leadership influence the success of the university. For example, the academic leader plays the role of bonding students, staff, and other stakeholders in the commitment to achieve the goals and objectives of the university. Success of the university depends on how effectively the leader builds academic climate and culture. This culture includes values, symbols, beliefs, and shared meanings of parents, students, teachers, and other stakeholders who are considered part of the university or college community (Sergiovanni, 1984; Vatican II, 1966).

In addition, there is a preference for leadership and management theories that emphasize notions of power vested in academic leaders to influence and direct followers in organizational action. In this vein, Morrison (2002) argues that no one individual can successfully demonstrate leadership in all contexts. Rather, a leader can draw on the tacit knowledge and capabilities of organizational members (Thomas, 2000). Clearly, this view promotes a holistic organizational 
leadership style that goes beyond individual knowledge and instead relies on what the group knows and does collectively (Spillane, Halverson, \& Diamond, 2001).

\subsection{Leadership Practices of the Catholic Universities System}

The Tanzania Catholic Bishops Conference represents 34 dioceses consisting of 33 on the mainland and one on the islands of Zanzibar and Pemba. Members of the Board of Trustees include five archbishops of the five metropolitan archdioceses of Tanzania and bishops of dioceses of the universities, colleges, and centres located in Tanzania. Current practices show that selection and appointments to university leadership positions in the past was perhaps ad $h o c$ at best and sometimes expedient rather than a result of careful, long-term searches.

In the Catholic Universities System, two main issues arise from appointment policies and procedures. First, appointments to senior leadership positions are made by owners of the institution with the advice of University Council. This is required by the University Charter (URT, 2010). The second stipulation is that because the institution is Catholic, it is expected to operate on the basis of values, traditions, and directives of the Catholic faith.

Consequently, these practices define the nature of the institution — private and Catholic - and therefore bring to the forefront issues related to leadership styles of leaders whose profile and traits fit the envisioned type of university organization. The nature and identity of Catholic universities claim special features with which to distinguish them from other types of universities. Throughout the history of the Catholic Church, individuals were appointed to leadership positions because they possessed the required qualities that reflected the character of the institution.

Further, several documents illustrate universities' special features and unique characteristics-for example, Sapientia Christiana (John-Paul II, 1979); the Declaration of Catholic Education, Gravissimum Educationis (Vatican Council II, 1966); and Bolarium Diplomatum, (Alexander IV, 1858). In recent years, Pope John Paul II (1990) in his letter, Ex Corde Ecclesiae (John Paul II, 1990), ("from the heart of the church"), outlined the nature of a Catholic university and the necessary qualities of leaders who become appointed to run them. He emphasized that a Catholic university is both a university and Catholic institution, and by its nature, it informs and carries out its research, teaching, and all other activities with Catholic ideals, principles, and attitudes (John Paul II, 1990). In other words, a Catholic university is expected to allow Catholic ideals, attitudes, and principles to inform the quotidian operations of the university so as to inspire or rekindle the wellbeing of the whole university (CIC, 2004). Therefore to be effective leader of a Catholic institution, one must adhere to these principles to avoid clashes with church authorities.

In the past few years, the 12 institutions of the Catholic Universities System witnessed several appointments of leaders made at different times. Between 2003 and 2005 when the colleges were fewer, the practice of appointments was based on a search by the Board of Trustees who relied on the "whom you know" strategy. Exceptions to this practice existed, particularly with medical school appointments. However, overall, academic leaders were appointed with a consideration of two qualities: first, is the candidate a priest? And second, does the candidate hold a doctoral degree?

Holding a doctorate degree is required by government regulations, and this requirement was ensured whenever an application for a new university was submitted for approval by the Tanzania Commission for Universities (TCU) or when proposals to expand the existing colleges were submitted. The documents must state whether the university or college's head had a doctoral degree. The practice of appointing a priest as academic leader emerged from the early colleges established by certain dioceses. At that time, diocesan bishops were asked to find a priest with a doctoral degree to run the institution.

In later years, the practice of bishops appointing academic leaders faded, and future appointees were required only to have doctoral degrees for all leadership positions. The assumption was that appointing individuals with doctorates to leadership positions implied that they had the capability, competence, and skills to lead a university. A tally of previous appointments shows that most of the Catholic priests with doctorates studied or obtained their degrees in Europe or the US. However, to be sure, priests who studied, for example, at the Gregorian University in Rome or Louvain University in Belgium and obtained a doctorate in moral theology or equivalent degree were specifically expected to teach at Catholic major seminaries in the country.

With the current pressures of competition, exigent need to meet the growing expansion, and quest for competent academic leaders of Catholic universities, the hiring procedures of senior management changed; and instead, the Board of Trustees allowed individuals with doctorates from Divinity universities (e.g., Gregorian or Louvain) to be appointed as academic leaders in the Catholic Universities System. To comply with diocesan regulations and traditions, the priests agreed to accept appointments and take on the charged responsibilities. But the challenges that arise from these practices are countless. For example: What leadership roles will be appropriate? How will they be 
determined? How does the institution influence leadership styles? Does leadership success depend on what the candidate studied, or must he/she go by intuition, using a trial-and-error method until the skills required to do a good job are attained? These questions sum up many of the complications associated with the current practice of appointments at new universities and colleges.

\section{Theoretical Perspectives}

Generally, leadership styles are strategies that become adapted to the particular demands of the situation such as the particular challenges facing the target institution (Murray, 1967), changes in management (Fullan, 2004), the particular requirements of the people involved and the ways they adapt to new situations or engage the practices of exemplary leadership to augment dire situations (Kouzes \& Posner, 2003); and constantly reminded of the human side of economic enterprise which is often fashioned from propositions and beliefs in human relations, historical and biographical factors (McGregor, 1985). In sum, each leadership situation is different and calls for particular types of leadership styles and innovative qualities of leadership. But the persisting question is: How can individual competencies be identified to facilitate the development of leadership talents and strategies? The present case study examined four core leadership theories that explain why some academic leaders succeed while others fail as leaders of an institution. These theories were amplified by modern leadership perspectives that include leader-member exchange, transformational concepts, emotional intelligence, authentic leadership, and innovation (Goleman, 1995). The four core theories are: (1) Trait theories, (2) Behavioral theories, (3) Contingency theories, and (4) Power and influence theories. Several common leadership styles have emerged from these core theories, but because of space limitations, this article examines only four core theories.

\subsection{Trait Theories - What Type of Person Makes a Good Leader?}

Trait theories argue that effective leaders share a number of common personality characteristics, or traits. Early trait theories showed that leadership is an innate, instinctive quality that individuals either have or not. Current thinking has evolved from this idea, and the trend is to discover what candidates can do to develop leadership qualities within themselves and others (Reinke, 2004). Trait theories help to identify traits and qualities (e.g., integrity, empathy, assertiveness, good decision-making skills, and likability) that are helpful when leading others. However, as shown recently by some scholars (Certo, 2010; Gill, 1983), none of these traits alone, nor any specific combination of them, can guarantee success as a leader. According to Certo (2010), many early studies summarized traits of successful leaders as intelligence, past achievements, emotional maturity and stability, dependability and consistency, social skills, and a desire for status and socioeconomic position.

\subsection{Behavior Theories - What Does a Good Leader Do?}

Behavior theories focus on how leaders behave in the workplace. For instance, do leaders dictate what needs to be done and expect cooperation? Or do they involve their teams in decision-making to encourage acceptance and support? Behavioral approaches to leadership styles view effective leaders as exhibiting certain consistent behaviors (Bass \& Bass, 2008; Miner, 2005). These behaviors divide leaders into those who are people-oriented and concentrate on follower satisfaction and motivation, while task-oriented leadership focuses on job performance. Development-oriented leadership encourages subordinates to become involved and solve problems. However, behavioural approaches have been criticized for failing to include situational factors that can influence leadership effectiveness (Carpenter, Bauer, and Erdogan, 2009).

In the 1930s, Kurt Lewin developed a framework based on leaders' behaviors. He argued that behaviors can be discerned in three types of leaders:

(1) Autocratic leaders - those who make decisions without consulting their teams. This style of leadership is considered appropriate when decisions need to be made quickly, when there's no need for input, and when team agreement is not necessary for a successful outcome;

(2) Democratic leaders - those who allow the team to provide input before making a decision, although the degree of input can vary from leader to leader. This style is important when team agreement matters, but it can be difficult to manage when there are lots of different perspectives and conflicting ideas; and

(3) Laissez-faire - these leaders avoid interfering; typically, they allow people within the team to make many of the decisions. This works well when the team is highly capable, is motivated, and doesn't need close supervision. However, this behavior can also indicate that the leader is lazy or distracted, which can lead to failure. 
Clearly, how leaders behave affects their success. Researchers have realized, however, that a variety of leadership behaviors may be appropriate at different times (Carpenter, Bauer, and Erdogan, 2009; Certo, 2010). They argue that the best leaders are those who can access different behavioral styles and choose the right mode for each situation.

\subsection{Contingency Theories - How Does Context Influences Effective Leadership?}

Contingency theories include situational and path-goal systems (Méndez-Morse, 2000). The main contribution of contingency approaches is recognition that different situational factors require different leadership approaches in order to achieve the desired goals (Saleemi and Bogonko, 1997). These contingency theories try to predict which leadership style is best in which circumstance. For instance, when a leader needs to make quick decisions, which style is best? And when one needs the full support of the team, is there a more effective way to lead? What then takes precedence: a people-oriented or task-oriented approach? And what contingency factors contribute to a leader's capacity to influence positive effects? Although it projects positive outcomes from following certain leadership styles, the contingency theory of leadership has been criticized for failing to provide an adequate explanation for how the interactions of personality and task situations lead to differentiated group performance (Lunenburg, 2012).

\subsection{Power and Influence Theories - What is the Source of the Leader's Power?}

Power and influence theories of leadership take an entirely different approach when compared to previously discussed theories. Power and influence theories are based on the different ways that leaders use power and their influence to accomplish their goals and then analyze the leadership styles that emerge as a result. Perhaps the best-known of these theories is French and Raven's Five Forms of Power (French \& Raven, 1959). This model highlights three types of positional power - legitimate, reward, and coercive - and two sources of personal power expert and referent (personal appeal and charm). French and Raven's model suggests that using personal power is a better alternative to positional power, and that a leader should work to build expert power (power that comes with being a real expert in the field) because this is the most legitimate source of personal power.

Another leadership style that uses power and influence is transactional leadership. This leadership style assumes that people are encouraged to do things for reward and perhaps for no other reason (Lunenburg, 2012).

In sum, these core theories - trait, behavior, contingency, and power and influence - explain why some academic leaders succeed in their positions, while others fail. For, being a successful academic leader is not about what individuals do (leadership roles) but rather how they do. Thus, the qualities of who they are and how they do (leadership styles) provide clues for examining why some academic leaders are successful - the quest for this study.

\section{Research Design and Findings}

Applying grounded-theory research techniques, a case approach was used to study reports, journals, and interview data collected during 2007 - 2013 from universities selected purposely to shed light on the dynamics of leadership roles found in the Tanzanian Catholic Universities System. The purpose of the study was to understand the dynamics and intricacies through constant comparative methods within the leadership styles based on leaders' behaviors (Lewin, 1947). Regarding this method, Clifford Geertz (1973) observed that "notes" and "data" must be read and reread to interpret and uncover key themes. Although generalizability is not possible or necessarily the goal, this method of reflective practice and analysis revealed basic assumptions about leadership roles within Catholic universities. Key themes from the literature were examined on a deeper level, including:

(a) The historical and socio-cultural traditions of Catholic universities (e.g., the Pope's encyclical documents) that impact the success of newly created institutions;

(b) The organizational culture of Catholic university programs; and

(c) The management framework (i.e., perspectives and overall practices of leadership styles, theory, and its impact on institutional change).

These themes were systematically used in this study to appraise and understand the dynamics and intricacies of academic leadership roles and management styles found in private universities and how leadership styles combine to shape the Tanzanian Catholic Universities System.

\subsection{Research Design}

A case study approach was selected because of the defined boundaries of the participants and the particular topic being researched (Creswell, 2007). The steps consisted of:

(a) Define the problem;

(b) Review literature for historical context of problem and current research on problem; 
(c) Select participants;

(d) Schedule interviews with select academic leaders;

(e) Transcribe interview data;

(f) Analyze reports and survey data; and

(g) Report outcomes.

\subsection{Participants}

Participants for this study came from a very select group of leaders. They were defined and purposely selected. These participants were required to be in a positon of leadership or able to discuss their perspectives of academic leadership or currently be employed in academic leadership positions in the Catholic Universities System within the past five years (2007-2012). Potential participants were identified by researching TCU's directory and from a list provided by the target universities. Since fully fledged universities were few, this task was relatively easy. An email request for participation was sent to each of the five potential participants outlining the focus of the research.

\subsection{Limitations}

Choosing participants to include only individuals employed in the Tanzanian Catholic Universities System imposed certain limitations, because those who represented other institutions might have had different perceptions of their leadership styles. But perhaps at this stage, to include participants outside the Catholic Universities System would have been beyond the scope of the present case study.

\subsection{Methods of Data Collection: Interviews}

To understand the foundation of qualitative research and essentials in grasping how participants view their world (Rossman \& Rallis, 2012,), the researcher conducted structured interviews with open-ended questions to uncover the assumptions and perceptions of university academic leaders. As explained previously, an academic leader was understood to be a person who had the ability and personality to influence the actions of others. Interviews were scheduled to take advantage of national meetings and seminars, and sometimes private scheduling was considered. Questions were designed to determine whether or not the assumptions of the leadership styles outlined by Goleman (1995) held true to the participating academic leaders.

The study followed Creswell's (2007) guidelines for conducting interviews: an audio recording device was tested prior to the interview and an interview protocol was created, tested, and refined. One-hour interviews were conducted one-on-one in participants' offices or at suitable private locations. The location was chosen primarily to accommodate participants' busy schedules and enabled the researcher to "develop a level of detail about the individual and place, and to be deeply immersed in the actual experiences of the participants" (Creswell, 2008, p. 181). For example, an interview of a participant from one of the first Catholic universities established in Tanzania revealed a pursuit to maintain a Catholic presence at the institution. This glimpse into the individual's working environment - the art surrounding the working place, religious articles, and entire campus atmosphere created a broader sense of the person's leadership style and relationship with the Catholic Universities System.

\subsection{Data Analysis}

According to Bogdan and Biklen (1998), "analysis involves working with data, organizing them, breaking them into manageable units, synthesizing, searching for patterns, discovering what is important and what is to be learned, and deciding what story will emerge from the data to tell others" (p. 157). Policy documents and university reports were analyzed to examine existing policies and explicit qualities presumed to guide the leadership of universities and colleges. The following documents were examined:

(a) Recommendations of the Tanzania Episcopal Conference University System (TEC, 2013);

(b) Tanzania Episcopal Conference: Higher Education Policy of the Catholic Church in Tanzania (2008);

(c) United Republic of Tanzania (URT): Universities Act (2005);

(d) Government Notice, No. 226: The universities' (General) Regulations (2013);

(e) Charter of Incorporation: Mwenge Catholic University (2013);

(f) University Qualifications Framework (2012);

(g) Tanzania University Level Education Employment of Staff Performance Review and Career Development—Minimum Guidelines (2012). 
Collectively, these documents provided guidelines for governance, human resources, autonomy, and university competence. They gave clues to the underlying assumptions, expectations, and dynamics that frame academic leadership roles. In turn, the government policy documents listed above provide general guidelines for all universities in Tanzania, including private universities. In addition, the Tanzania Episcopal Conference actively regulates the Catholic institutions in Tanzania as enunciated here:

(1) Identity of a Catholic institution; for example:

a. "A Catholic institution of higher learning shall ensure that its Catholic identity is indicated in its mission statement and operates according to the Catholic ideals, principles and values" (TEC, 2013, p. 14).

b. A Catholic institution shall always maintain a Catholic environment by ensuring that Catholics are being faithful to Catholic principles and morals in their teaching and research (TEC, 2013).

c. The Church's vision on education has been developed to be "the provision of quality and integral education to the children of God ... The Church's mission on University Education is the continuous quest for truth through research and the preservation of knowledge for the good of the society" (TEC, 2013, p. 13).

(2) Autonomy; for example: "A Catholic institution of Higher Learning shall be autonomous in matters of governance" (TEC, 2013, p. 23).

(3) Competence; for example: "The principal officers and staff of institutions of higher learning shall be appointed on merit and in an open system that inspires confidence, fairness, competence and accountability" (TEC, 2013, p. 23).

(4) Governance; for example: "The appointment procedures of the lecturers and administrators shall ensure that appointees respect the Catholic-identity status of the institution though they do not all have to be Catholics ... The principal officers and staff of institutions of higher learning shall have control of the institutions' management and administrative matters, in accordance with their constitutions" (TEC, 2013, p. 24).

Additionally, these documents revealed that there was an evolution in academic leadership positions taking place quietly and guided from time to time by Board of Trustee meetings, University Council sittings, and University Academic Committee meetings.

\subsection{Interviews}

Five open-ended interview questions were designed to determine whether Goleman's assumptions about leadership styles held true to the participants. Goleman and his team completed a three-year study with over 3,000 middle-level managers to uncover specific leadership behaviors and determine their effect on the corporate climate, and each leadership style's effect on bottom-line profitability. Using Goleman's assumptions on leadership styles, this study attempted to seek responses to the following:

(1) What type of person makes a successful leader? (Effective leader);

(2) What does a good leader do? (Leadership roles/styles);

(3) How does the situation influence good (effective) leadership? (Leaders' influence on others); and

(4) What is the source of the leader's power? (Challenges and source of leader's power).

The goal here was to use this case approach to examine the assumptions, expectations, and dynamics that academic leaders use to frame their academic leadership roles within Tanzania's Catholic Universities system.

Four individuals volunteered to participate in the interview process. All participants were promoted through the university system from lecturer to the top position of vice chancellor. Some of these individuals had multiple experiences in both the Catholic system as well as working with government institutions. One individual had just finished his term as vice chancellor at one of the private universities in Tanzania. He had broad experience as university corporate counsel and secretary to the Board of Trustees. He seemed very knowledgeable about university policies and the culture of the university in general. He served the position of vice chancellor for ten years. Collectively, the four individuals were middle-aged or close to retirement.

\subsection{Theme 1: Effective Leadership}

Participants commented on their experiences as academic leaders. They all agreed that to be a successful academic leader it was imperative to understand the policies and particularly to adhere to the mission and vision of the university. One participant stated, 
[A] Vice Chancellor as an effective academic leader must have a vision for the university on the academic matters so that the expected outputs would be academic - making sure that the learning and teaching, the research and development of new knowledge. . is accomplished according to the standards expected worldwide - because the university is not only to meet the wishes of the students but also to comply with the demands of other regulators like the government and other international communities. (30-03-2015)

Another comment reflected the vision:

As a leader, you must have a vision - a person who sees beyond and can assure people that we are not sinking, [and that] we are actually heading somewhere and [that] we will overcome all these challenges, these problems because the leader has a vision." (30-03-2015)

\subsection{Theme 2: Leadership Roles and Styles}

A leader works to create emotional bonds that bring a feeling of bonding and belonging to the organization. Sometimes the team needs a visionary, a new style of coaching, someone to lead the way or even on occasion, a push. For that reason, great leaders choose their leadership style with calculated analysis of the matters at hand, the end goal, and the best tool for the job. One of the participants stated the following:

Leadership is by example — one simple example that I learned is Management by walking around (MBWA), like a soldier on a beat-you may think things are going on well until you visit the library and you realize there is something wrong in the library, in the IT [department], etc... Your ears must always be open to listen to what people are saying. Hence being close to the staff and students, being fair, leading by example, integrity, [and] no double standards, lead[ing] by walking around ... (19-03-2015)

"Soldier" refers to the authoritative leadership style, which works best when the team needs a new vision because circumstances have changed or when explicit guidance is not required. Authoritative leaders may inspire an entrepreneurial spirit and vibrant enthusiasm for the mission.

\subsection{Theme 3: Leaders' Influence on Others}

According to Goleman, "people come first" (Goleman, 1995). A leader will want to help teams or groups to build lasting personal strengths that make them more successful overall. One participant stressed: "[Y]ou cannot work alone, you always have to work with those under you; the human resource personnel, the planners, the bursar and the financial office as well as the top management" (26-03-2015).

In addition, the participants talked about the many roles they play in the position of academic leader. For example, the academic leader plays the role of bonding students, staff, and other stakeholders in the commitment to achieve the goals and objectives of the university. Participants insisted that success of the university depends on how effectively the academic leader builds academic climate and culture. This culture was found to include values, symbols, beliefs, and shared meanings of parents, students, teachers, and other stakeholders who are considered part of the university or college community.

\subsection{Theme 4: Challenges to and Sources of Leaders' Power}

In the African perspective, leadership is viewed as power of commanding authority or influence within a group (Mbiti, 1990). In fact, in Africa, a leader is viewed as someone who is a servant to the clan, tribe, community, or group (Masango, 2002). In practice, however, African people treat a leader as a King, priest, or ruler chosen by virtue of the office in order to serve the nation (e.g., Masango, 2002,). The participants' views on the leader's power concurs with Masango (2002) and Nahavandi (2000), who suggest that leadership always involves interpersonal influence or persuasion. Thus, leaders use influence to guide groups of people through certain courses of action or towards the achievement of certain goals. The presence of leaders assumes "some form of hierarchy within a group; that is, it refers to the power of leadership" (Masango, 2002, p. 708). One participant said, "[T]his is very much culturally conditioned because on my side being in Africa, in Tanzania, where people are still dependent on the Top-Down leadership style whereby it is taken that once something is said by the head of the institution, [it] must be done-that's final!" (30-03-2015).

Another participant was articulate about the hierarchy of power. He said:

Both public and private universities had authorities one had to listen to. On the part of the government, there was the minister, the party, and the State House; while for the Church, there were the top organs at the Diocesan level. One thing that I learned from both parties is, which is extremely useful, to know their thinking and to know their expectations - otherwise you will get stuck. (19-03-2015) 
The study showed that to be successful as an academic leader, transparency, integrity, consistency, and involving others in the leadership and being a good listener are of paramount significance. For example, one participant said: "[T] he question of integrity, academic background, the delegation of power, regular contacts, tells you when and how to meet the students and when to meet all workers irrespective of whether they are professors or cleaners" (2015, March 16).

In this vein, Morrison (2002) argued that no one individual can successfully demonstrate leadership in all contexts. Rather, a leader can draw on the tacit knowledge and capabilities of organizational members. Clearly, this view promotes a holistic organizational leadership style that goes beyond individual knowledge and instead, relies on what the group knows and does collectively (Spillane, et al. 2001).

\section{Conclusion and Lessons Learned}

This case study examined the dynamics of leadership roles exhibited in private universities and showed how leadership styles align with the Catholic Universities System in Tanzania. The study indicated that the Catholic Universities System occupies a unique place in Tanzania's society, and it presents its mission as both Catholic, pastoral, and private. In Tanzania a Catholic private institution is distinguished from semi-private institutions (e.g., district hospitals, government run libraries at private secondary schools, and water wells). In addition, the study revealed several dynamics that successful academic leaders apparently need to develop or must have to permit interpersonal relationships with those they lead. The first dynamic was that team work and collaboration were of paramount importance. Collectively, the findings underscored the need to be visionary in order to be able to lead others to meet the goals of the university's mission.

A second dynamic that influenced the success of academic leaders at private universities, where the day-to-day operations of the institution did not rely on government budgets or dictates, had to do with the charisma of the leader in influencing others to action. The study noted some participants made reference to situations in which they appointed chairs of university committees and other individuals to leadership positions of deans or department heads. The roles they played did not by any means diminish the importance of leadership styles. Therefore, the key to having successful leadership tenure is a leader must enable others to grow in the understanding of the structure of the university in order to commit their efforts to the mission of the university.

A third dynamic that emerged from the study is culture. The study concluded that leadership at an African institution embeds an African cultural dynamic. Cultural dynamics seem to govern, sustain, and sometimes frustrate leadership appointments. Clearly, the undercurrents of kinship, gender, and ethnicity held sway on perceptions of how decisions regarding appointments are made.

In sum, the three dynamics exposed in this study demonstrate that performance of leaders in private universities can be influenced by the qualities of academic leadership style. Goleman's assumptions were important in this study and instrumental to identify the different roles and styles appointees bring to the job. Equally, the styles conjure deep assumptions that undergird the expectations of management operations, as well as leadership qualities, which in turn, were perceived by incumbent academic leaders as critical to their success.

In addition, the study noted that cross-cultural forces of kinship, gender, and ethnicity can make or break the success of a private university because such obstacles can govern, sustain, and sometimes frustrate leadership appointments. The study concurs with Goleman's (1995) observation that there is no "magic combination" of characteristics that make a leader successful and that different characteristics matter in different circumstances. However, this does not mean that a novice leader cannot learn to be an effective leader; rather, a leader needs to understand the various approaches to leadership in order to use the right approach to match the situation as well as the institution.

To address the limitations of the present study, future research should expand the population of academic leaders to include all private and public universities/colleges. In addition, it will be interesting to compare leadership styles and the ways in which they align with each type of higher learning institution, public and private.

\section{References}

Bass, B. M., \& Bass, R. (2008). The Bass handbook of leadership: theory, research, and managerial applications. 4th Edition. New York: Free Press.

Bogdan, R. C., \& Biklen, S. K. (1998). Qualitative research in education: An introduction to theory and methods. (3rd Edition.).Boston, MA: Allyn and Bacon.

Carlyle, T., (1841). On heroes, hero worship and the heroic in history. Boston: Adams.

Carpenter, M. A., Bauer, T., \& Erdogan, B. (2009). Principles of management. Washington: Flat World Knowledge. 
Certo, S. C. (2010). Supervision: Concepts and Skills-building. 7th Edition. New York: McGraw-Hill/Irwin.

Creswell, J. W., (2007). Qualitative inquiry \& research design: Choosing among the five approaches. Thousand Oaks, CA: Sage Publications.

Creswell, J.W. (2008). Research Design: Qualitative, Quantitative, and Mixed Methods Approaches. $3^{\text {rd }}$ Edition. Thousand Oaks, CA: Sage Publications.

D'este, P., \& Perkmann, M. (2011). Why do academics engage with industry? The entrepreneurial university and individual motivations. The Journal of Technology Transfer, 36(3), 316-339. http://dx.doi.org/10.1007/s10961-010-9153-z

Fullan, M. (2004). Leading in a culture of change: Personal action guide and workbook. San Francisco, CA: Jossey Bass.

Gangani, N., McLean, G., \& Braden, R. (2006). A competency-based human resource development strategy. Performance Improvement Quarterly, 19(1), 127-140. http://dx.doi.org/10.1111/j.1937-8327.2006.tb00361.x

Geertz, C. (1973). The Interpretation of Cultures. New York: Basic Books.

Gibb, A. (2012). Exploring the synergistic potential in entrepreneurial university development: towards the building of a strategic framework. Annals of Innovation \& Entrepreneurship, 3. http://dx.doi.org/10.3402/aie.v3i0.16742

Goleman, D. (1995). Emotional Intelligence. New York: Bantam Books.

Gorton, R. (1987). School leadership and administration: Important concepts, case studies and simulations. Dubuque, IA: Brown Publishers.

Harding, T. (2010). Fostering creativity for leadership and leading change. Arts Education Policy Review, 111(2), 51-53. http://dx.doi.org/10.1080/10632910903455827

Hord, S. M. (1992). Facilitative Leadership: The Imperative for Change. Austin, TX: Southwest Educational Development Laboratory.

John Paul II. (1980). Discourse to the Institute Catholique de Paris. Vatican: Liberia Editrice Vaticana.

John Paul II. (1990). Apostolic Constitution of the Supreme Pontiff on Catholic Universities Vatican City: Liberia Editrice Vaticana.

Kenya Secondary School Heads Association. National Conference. (1999). Presentation at the 1999 National Conference in Mombasa. Nairobi: Kenya Secondary School Heads Association

Knight P. \& Trowler, P. (2001). Departmental Leadership in Higher Education. Buckingham, UK: Open University Press.

Kouzes, J \& Posner, B. (2003). The leadership challenge. 3rd Edition. San Francisco, CA: John Wiley.

Lewin, K. (1947). Frontiers of group dynamics: concept, method and reality in social science, social equilibria, and social change. Human Relations, 1, 5-41. http://dx.doi.org/10.1177/001872674700100103

Lunenburg, F.C. (2012). Power and Leadership: An Influence Process. International Journal Of Management, Business, And Administration Volume 15, Number 1.

Marshall, S. P. (2006). The power to transform: Leadership that brings learning and schooling to life. New York: Jossey-Bass

Marshall, S.J., Orrel, J., Cameron A., Bosanquet A., \& Thomas, S. (2011). Leading and Managing learning and teaching in higher education. Higher Education Research and Development 30(2): 87-103. http://dx.doi.org/10.1080/07294360.2010.512631

McGregor, D. M. (1985). The human side of enterprise. New York: McGraw-Hill. http://dx.doi.org/10.1016/b978-0-12-054752-4.50008-7

Masango, M. (2002). Leadership in the African context. Verbum Dei Ecclesia, JRG 23(3), 707-718). http://dx.doi.org/10.4102/ve.v23i3.1234

Mbiti, J. S. (1990). African religions \& philosophy. New York: Heinemann.

Méndez-Morse, S. (2000). Claiming forgotten leadership. Urban Education, 35(5), 584-596. http://dx.doi.org/10.1177/0042085900355008 
Miner, John B. (2005). Organizational behavior: essential theories of motivation and leadership. Armonk, NY: M. E. Sharpe.

Murray, A. (1967). The Wall Street Journal Guide to Management. New York: Harper Business.

Mwenge Catholic University. (2013). Charter of incorporation. Moshi: MWECAU.

Nahavandi, A. (2000). The Art and Science of Leadership. $2^{\text {nd }}$ Edition. New Jersey: Prentice Hall, Upper Saddle River.

Pope Alexander IV (1858). The letter of Pope Alexander IV to the University of Paris, 14 April 1255. Introduction. Bolarium Diplomatum, Vol. III. Turin: Liberia Editrice Vaticana.

Pope John Paul II (1979). Apostolic Constitution Sapientia Christiana-Ecclesiastical Universities and Faculties. Pp. 469-521.

Reinke, S. J. (2004). Service before self: Towards a theory of servant leadership. Global Virtue Ethics Review, 5(3), 30-57.

Rossman, G .B, \& Rallis, S.F. (2011). Learning in the Field: An Introduction to Qualitative Research. $3^{\text {rd }}$ Edition. Thousand Oaks, CA: Sage Publications.

Saleemi, N. A. and Bogonko, J. B. (1997). Management (Principles and Practice). Simplified. Nairobi: N.A. Saleemi Publishers.

Sankowsky, D. (1995). The charismatic leader as narcissist: Understanding the abuse of power. Organizational Dynamics, 23(4), 57-71. http://dx.doi.org/10.1016/0090-2616(95)90017-9

Sergiovanni, T. (1984). Leadership and excellence in schooling. Educational Leadership, 41(5): 4-13.

Spillane, J., Halverson, R., \& Diamond, J. (2001). Investigating school leadership practice: A distributed perspective. Educational Researcher, 30(3): 23-28. http://dx.doi.org/10.3102/0013189X030003023

Tanzania Commission for Universities (TCU). (2012). University qualifications framework. Dar es Salaam: TCU.

Tanzania Episcopal Conference (TEC). 2008. Tanzania Episcopal Conference: Higher education policy of the Catholic Church in Tanzania. Dar es Salaam: Department of Education.

TCU (2012). Tanzania University Level Education Employment of Staff Performance Review and Career Development-Minimum Guidelines. Dar es Salaam: TCU.

TEC (2013). Universities guidelines: Recommendations of the Tanzania Episcopal Conference University System.

Thomas, K. (2000). Intrinsic motivation at work. San Francisco: Barrett-Koehler Publishers.

Uben, G., Hughes, L., \& Norris, C. (2001). The principal: Creative leadership for effective schools. 4th Edition. Boston: Allyn and Bacon.

URT. United Republic of Tanzania. (2010). The Mwenge University College of Education Charter, 2010: Charter and Rules 2010. Dar es Salaam: The State House.

Vatican Council II (1966). Declaration on Catholic Education, Gravissimum Educationis, (no. 10). Vatican City: Liberia Editrice Vaticana, p. 737.

Vatican II, 1966. Pastoral Constitution on the Church in the modern world, Gaudium et Spes. No. 53. Vatican City: Liberia Editrice Vaticana. 